\title{
PENGUATAN MODAL SOSIAL BERBASIS KELEMBAGAAN LOKAL MASYARAKAT PESISIR PERSPEKTIF GENDER DI KABUPATEN BANTUL
}

\author{
Oktiva Anggraini ${ }^{1}$ dan Muhammad Agus ${ }^{2}$ \\ ${ }^{\prime}$ Dosen Universitas Widya Mataram Yogyakarta \\ ${ }^{2}$ Dosen Universitas Pekalongan \\ e-mail: oktivabiyan@yahoo.co.id
}

\begin{abstract}
The aim of this research is getting to know: encouraging the creation of social capital empowerment in the empowerment of fisherman based local institution with gender perspective in coastal area of Bantul regency. With descriptive qualitative research design, data collection techniques: in-depth interview; literature study, observation and FGD. The results showed that coastal villages in Bantul district have developed institutions and rules that effectively limit the rate of exploitation of natural resources. Characteristic of social capital of coastal community in research location indicated that dominant group is group of citizen (regular social gatherings, rotating saving clubs) fisherman group and fisherman. Given that the dominant group resides in the internal environment of the settlement and consists of the settlement community itself, access to outside resources is limited. The level of participation in the group was quite good seen from the presence, material and non-material. The level of trust and solidarity is relatively high. Values are still firmly held and result in collective action and cooperation is relatively good enough. Social capital was more used for the fulfillment of daily needs (subsistence), is temporary and very personal. There was still a less supportive local culture, a wasteful life. Not many types of services could be expanded access because of the existence of a limited group. Social capital that supports the management of tourist destinations and coastal community empowerment in general need strengthening of related institutions, especially Marine and Fisheries Official, Tourism and Education Official, Industry and Commerce Official in Bantul regency more integrated. The caution of the coastal empowerment initiators resulted in coastal communities in Bantul district failing to develop social capital in the context of managing government resources such as bangdes funds, etc.
\end{abstract}

Key words: social capital, gender, collective action,empowerment.

\section{PENDAHULUAN}

Marginalisasi perempuan dalam berbagai sektor pembangunan menjadi masalah global dan hal ini nampak nyata pada peran perempuan di sektor perikanan dan kelautan. Terutama ketika analisis gender dalam komunitas perikanan tidak sekedar membicarakan perbedaan peran lakilaki dan perempuan, akan tetapi pada persoalan pengambilan keputusan dalam proses dan pemanfaatan pengelolaan sumber daya kelautan yang pada gilirannya, memunculkan kebijakan kebijakan pemerintah yang lebih menitikberatkan perhatian pada sektor penangkapan ikan yang belum sepenuhnya berpihak pada perempuan (Bennet, 2004).

Sementara itu, wajah lain dari pembangunan, pengurangan kemiskinan di antaranya dengan mengurangi kerentanan masyarakat miskin dan persoalan kesetaraan gender di bidang perikanan dan kelautan menjadi kian penting. Lebih dari 45 juta penduduk dunia bergerak di sektor perikanan dan kelautan baik sebagai pekerja tetap maupun sambilan. Dari 86 negara, 5,4 juta wanita bekerja di sektor kelautan dan perikanan, bahkan di Cina dan India, jumlah wanita nelayan mencapai $24 \%$, lebih dari $60 \%$ hasil perikanan dipasarkan oleh wanita nelayan (FAO, 2012). Sungguhpun wanita nelayan memiliki andil yang cukup besar, untuk mewujudkan pengelolaan sumberdaya kelautan menjadi rantai bernilai bagi nelayan dan wanita nelayan untuk berkiprah bersama, tidaklah mudah.

Fenomena di tingkat lokal, tidak jauh 
berbeda, meski melalui RKPD (Rencana Kerja Pembangunan Daerah) Kabupaten Bantul tahun 2012 telah diatur pengarasutamaan gender di bidang pertanian, termasuk perikanan dan kelautan dalam implementasinya dijumpai ketimpangan gender. Ini mengisyaratkan, regulasi saja tidak cukup, riset-riset sebelumnya (Anggraini, 2006; 2011; 2013; Sahudiyono, 2009) menunjukkan bahwa wanita nelayan sebagai salah satu komponen penting dalam pengelolaan pesisir lebih sering terbatas dalam akses modal, informasi, teknologi dan jarang diikutsertakan dalam pengaturan regulasi berbagai program pemberdayaan. Akibatnya, pengelolaan sumber daya potensi pesisir tidak optimal dan penguasaan sumber daya tidak seimbang antara laki-laki dan perempuan. Tantangan lain bahwa penguatan ekonomi lokal melalui lembaga modern seperti Swa Mitra Mina dan bank-bank swasta, cukup resisten dan seolah menjadi ancaman bagi organisasi ekonomi lokal (Anggraini 2006, 2013). Proses pemberdayaan ekonomi melalui PNPM Mandiri Pariwisata \& PNPM MKP (Laporan PNPM DIY, 2010; Sahudiyono, 2009) belum diikuti penguatan lembaga lokal, yang memberi ruang partisipasi yang lebih luas bagi wanita nelayan sehingga proses peningkatan kapasitas pun belum banyak dinikmati anggota. Bantuan justru menyebabkan modal sosial masyarakat berupa kejujuran dan kegotong-royongan terkikis. Kelompok nelayan dan kelompok wanita nelayan binaan Diskanla Kabupaten Bantul belum seluruhnya mampu memanfaatkan modal sosial untuk meningkatkan usahanya, yang tercermin dari keterbatasan akses, partisipasi, kontrol dan manfaat yang diterima.

Modal sosial tersebut mengacu pada aspek-aspek utama dari organisasi sosial, seperti kepercayaan, norma-norma dan jaringanjaringan yang dapat meningkatkan efesiensi dalam masyarakat melalui fasilitas bagi tindakan-tindakan yang terkoordinasi. Elemen pokok modal sosial meliputi: (1) saling percaya, (2) kejujuran, (3) pranata yang meliputi nilai-nilai yang dimiliki bersama, norma-norma dan sanksi-sanksi. Elemenelemen tersebut dalam dinamikanya harus dikreasikan dan ditransmisikan melalui mekanisme-mekanisme sosial budaya di dalam sebuah unit sosial seperti keluarga, komunitas, asosiasi sukarela, negara dan sebagainya. Hal-hal tersebut juga akan terwadahi dalam beberapa modal sosial yang bersifat horizontal, seperti paguyuban, asosiasi, organisasi lokal, jaringan sosial dan dilandasi dengan norma dan nilai yang mengacu pada solidaritas, toleransi, kepercayaan dan kerjasama (Eko, 2004; Fukuyama, 2005; Hasbullah, 2006; Hermawanti, dan Hesti Rinandari, 2002).

Dalam masyarakat pesisir yang memiliki keterbatasan sumber daya fisik dan ekonomi maka modal sosial dalam bentuk rasa percaya (trust) dan norma timbal-balik (norm of reciprocity) dimanfaatkan untuk memperoleh kedua sumber daya tersebut untuk kegiatan penangkapan ikan (Wahyuni, 2007). Ini terlihat dari hubungan hutang dan patronklien. Dalam hal ini modal sosial bermanfaat karena menurunkan biaya transaksi (transaction cost) dalam melakukan kegiatan ekonomi yaitu penangkapan ikan, dan eksternalitas terbatas bagi individu atau jaringannya; meskipun praktek ini sesungguhnya meluas (Kusnadi, 2002).

Selain itu modal sosial juga dapat dilihat sebagai aksi bersama untuk mengelola sumber daya milik komunal melalui aturan dan sanksi. Ostrom (1990) menyatakan ada 2 kriteria yang memberikan batasan mengenai sumberdaya self-organized common-pool resources atau sumberdaya yang dikelola secara mandiri: (1) ada biaya yang digunakan untuk melindungi dan melarang pihak lain untuk mengeksploitasi sumber daya, (2) sumber daya terbatas sehingga bila dimanfaatkan terus dapat habis. Dalam hal ini modal sosial bermanfaat karena menurunkan biaya transaksi (transaction cost) dalam melakukan kontrol terhadap upaya tangkap, yang dapat dilakukan melalui pembatasan pelaku perikanan, ekstraksi sumber daya pada musim tertentu, penggunaan alat tangkap tertentu dan sebagainya.

Berangkat dari fenomena tersebut, penelitian ini ingin mengkaji secara komprehensif dan terintegrasi dalam mendorong terciptanya penguatan modal sosial dalam pemberdayaan nelayan berbasis kelembagaan lokal berperspektif gender di wilayah pesisir kabupaten Bantul.

\section{METODE PENELITIAN}

Penelitian ini menggunakan desain kualitatif. Pengumpulan data primer melalui wawancara terstruktur, FGD dan pengamatan langsung. FGD dilaksanakan di 4 (empat) lokasi TPI dengan mengundang perwakian narasumber 
stake holders. Informan kunci dalam in-depth interview, aparat dari:Dinas Perikanan dan Kelautan, Dinas Pariwisata 5 orang, 15 pengurus koperasi dan KUB nelayan/wanita nelayan kelembagaan lokal mitra sosial nelayan kecil dan 5 para pengelola kelembagaan lokal pesisir, 6 wanita nelayan, 7 nelayan di kabupaten Bantul. Pengumpulan data sekunder melalui penelusuran arsip dan dokumen yang terkait. Guna menjamin validitas data dilakukan triangulasi sumber data dan metodologi.

\section{HASIL DAN PEMBAHASAN}

Kabupaten Bantul merupakan salah satu bagian dari Wilayah Daerah Istimewa Yogyakarta yang memiliki potensi yang strategis dalam bidang sosial, ekonomi, dan budaya. Kabupaten Bantul terletak antara $110^{\circ} 12^{\prime} 34^{\prime \prime}$ sampai $110^{\circ} 31^{\prime} 08^{\prime \prime}$ bujur timur dan $07^{\circ} 44^{\prime} 04^{\prime \prime}$ sampai $00^{\circ} 00^{\prime} 27^{\prime \prime}$ lintang selatan. Kabupaten Bantul secara administratif terdiri dari 17 kecamatan, 75 desa/kelurahan, 933 pedukuhan, dan 5.818 Rukun Tetangga (RT). Luas wilayah darat Kabupaten Bantul adalah $50.685 \mathrm{Ha}$ atau $506,85 \mathrm{~km} 2$, dengan panjang garis pantai \pm 17 $\mathrm{km}$ dan lebar laut 4 mil, sehingga wilayah laut Kabupaten Bantul mencapai $\pm 125,936 \mathrm{~km} 2$. Kabupaten Bantul dilalui 6 sungai, yaitu: Sungai Oya, Sungai Opak, Sungai Progo, Sungai Winongo, Sungai Code, dan Sungai Bedog dengan panjang total keenam sungai tersebut mencapai $114 \mathrm{~km}$. Menurut data Badan Pusat Statistik, jumlah penduduk di Kabupaten Bantul pada tahun 2010 sebanyak 911.503 orang. Angka tersebut bertambah menjadi 930.276 orang pada tahun 2012 (hasil proyeksi Sensus Penduduk 2010).

Sektor kelautan dan perikanan Kabupaten Bantul mempunyai potensi ekonomi yang sangat tinggi. Pengelolaan potensi kelautan dan perikanan di Kabupaten Bantul terus diupayakan demi kemakmuran masyarakat tanpa meninggalkan aspek kelestariannya. Peningkatan perekonomian masyarakat yang diikuti kesadaran akan pentingnya mengkonsumsi ikan menimbulkan implikasi meningkatnya permintaan ikan dan produk olahannya. Keadaan ini merupakan peluang bagi berkembangnya sektor kelautan dan perikanan khususnya di Kabupaten Bantul.

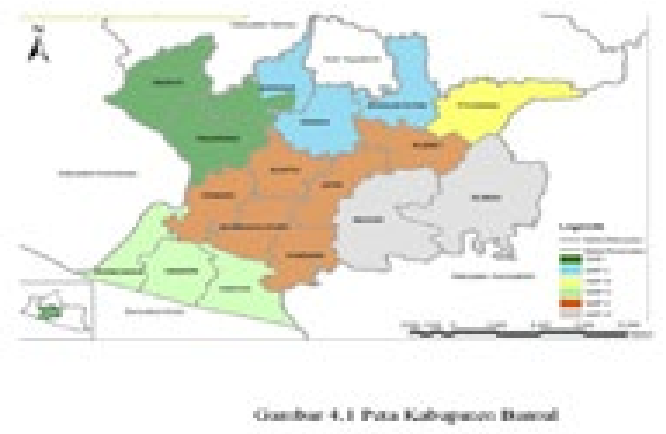

Gambar 1. Peta Kabupaten Bantul

Bantul dengan topografi sebagian besar masuk sebagai dataran rendah mempunyai potensi yang sangat besar dalam pengembangan perikanan khususnya perikanan budidaya. Dinas Kelautan dan Perikanan Kabupaten Bantul terus berusaha meningkatkan produksi perikanan budidaya dengan menerapkan berbagai strategi pengembangan seperti peningkatan SDM, aplikasi teknologi, bantuan akses permodalan dan peningkatan kapasitas kelompok pembudidaya ikan (Pokdakan).

Perkembangan sektor kelautan dan perikanan di Kabupaten Bantul tidak bisa terlepas dari ketersediaan sarana dan prasarana serta kelembagaan yang ada di masyarakat. Keterpaduan beberapa hal tersebut menjadi motor penggerak peningkatan produksi.

Tabel 1. Sarana dan Prasarana Kelembagaan Kelautan dan Perikanan

\begin{tabular}{|c|c|c|c|}
\hline No & Jenis & 2011 & 2013 \\
\hline 1. & TPI & 6 & 6 \\
\hline 2. & Pasar Ikan & 7 & 7 \\
\hline 3. & Kapal & 5 & 7 \\
\hline 4. & $\begin{array}{l}\text { Perahu Motor Tempel } \\
(\mathrm{PMT})\end{array}$ & 77 & 116 \\
\hline 5. & $\begin{array}{l}\text { UPR (Unit Pembibitan } \\
\text { Rakyat) }\end{array}$ & 61 & 62 \\
\hline 6. & $\begin{array}{l}\text { Pokdakan (Kelompok } \\
\text { Pembudidaya ikan) }\end{array}$ & 577 & 740 \\
\hline 7. & Poklaksar & 29 & 50 \\
\hline 8. & $\begin{array}{l}\text { Pokmaswas (Kelompok } \\
\text { MasyarakatPengawas) }\end{array}$ & 26 & 26 \\
\hline
\end{tabular}

Sumber:Data DKP 2013

Berdasar tabel 1 sarana kapal nelayan nampak mengalami peningkatan $2 \%$. Kepemilikan perahu tempel bertambah dari 77 menjadi 116 atau 39\% sedangkan unit pembibitan rakyat mengalami peningkatan 
sedikit $1 \%$, jumlah polaksar meningkat $21 \%$ dan pembudi daya ikan mengalami peningkatan signifikan sebesar $163 \%$, sedangkan jumlah pokmaswas tetap.

\section{Ketersediaan Kelompok dan Jejaring Kerja}

Keluasan jaringan kerja dari suatu kelompok masyarakat tercermin dari kesediaan warga bermitra antar sesama; keterbukaan dalam berhubungan dengan kelompok nelayan yang lain dan keaktifan memelihara hubungan baik di antara kelompok.

Data empiris menunjukkan bahwa kelompok yang terdapat di desa pesisir kabupaten Bantul relatif banyak dan beragam, mulai dari kelompok keagamaan, kelompok tani/nelayan, kelompok pedagang, kelompok profesi, serikat pekerja, kelompok warga, parpol, kelompok pemerhati budaya, kelompok arisan, kelompok pemuda, kelompok olahraga, mitra tani, komite sekolah, bahkan LSM/ormas.

Banyaknya kelompok yang tersedia di masyarakat ini ternyata tidak berkorelasi dengan tingkat keaktifan masyarakat dalam berpartisipasi karena mayoritas informan menilai bahwa partisipasi mereka dalam kelompok yang diikutinya justru lebih sedikit dibanding dengan tiga tahun yang lalu. Penyebabnya beragam, terutama disebabkan kesibukan dalam bekerja karena makin mahalnya kebutuhan hidup sehari-hari menyebabkan informan banyak yang berkonsentrasi untuk mencari nafkah, sementara kegiatan di kelompok cenderung hanya sebagai sampingan bila ada waktu luang.

Mayoritas warga pesisir menyediakan waktu sebanyak $8-10$ kali dalam satu bulan untuk hadir dalam pertemuan-pertemuan yang diselenggarakan kelompok. Sedangkan para pengurus kelompok meluangkan waktu lebih banyak, untuk rapat intern pengurus maupun menghadiri undangan-undangan di luar kelompok atas nama kelompok.

Keanggotaan warga dalam kelompokkelompok tersebut sebagian besar karena diajak untuk bergabung atau bergabung secara sukarela. Tidak ada warga yang merasa terpaksa menjadi anggota suatu kelompok mengingat warga tersebut memiliki tujuan bersama yang hendak dicapainya yang tidak bisa dicapai, tanpa berkelompok. Rujito adalah salah satu pemuka masyarakat, pelindung habitat penyu di pantai Samas. Sebagai pemrakarsa, dirinya menyadari betul arti berkelompok, sejak ia tinggal di daerah tersebut, dinamika masyarakat berkelompok dalam pelestarian penyu mengalami pasang surut. Ia melukiskan sulitnya menyadarkan warga sendirian. Dengan berkelompok, kesadaran warga lambat laun meningkat berikut dengan bantuan dari berbagai pihak, terutama pemerintah dalam hal pelestarian penyu. Tahun 2014, pihaknya menjaring CSR Pertamina untuk membangun gazebo penyu, bantuan dari Philipina dan Amerika untuk penetasan telur. UGM yang secara rutin membantunya, acapkali menggelar event pelepasan tukik, anak penyu, yang dihadiri mahasiswa dan pelajar. Hal yang sama dalam hal berjejaring, pemuka masyarakat di pantai Goa Cemara bekerja sama dengan LSM Save Turtle mengkampanyekan pelestarian penyu. Observasi menunjukkan sejumlah pamflet dan billboard besar yang berisi himbauan "Save Turtle" terpampang di berbagai tempat di Goa Cemara. CSR perguruan tinggi dan Bank Swasta serta BMT tahun 2012 membantu sejumlah fasilitas seperti perbaikan gazebo pengunjung, papan informasi wisata.

Pemerintah sendiri tak kalah perhatiannya, tahun 2010 memperbaiki fasilitas pasar untuk pedagang non ikan dan terminal pengunjung serta konblokisasi jalan setapak. Sebagaimana yang ditegaskan Katno, ketua kelompok Darwis Goa Cemara berikut:

" melalui rembug kelompok, banyak usulan masuk lalu kami himpun, kita ajukan ke Dinas DKP atau Dinpar Bantul. Dari sana, kita diminta mengajukan proposal, akhirnya kita tindaklanjuti dan tidak lama kemudian bantuan terealisasi" (wawancara dengan bapak Katno, Juli, 2014).

Fakta di atas menguatkan pendapat tim peneliti bahwa tidak sulit bagi warga pesisir Bantul untuk menjaring kepedulian dari berbagai pihak bagi pengembangan pengelolaan sumber daya kelautan. Manfaat paling besar yang diperoleh dari keanggotaan kelompok adalah pemenuhan kebutuhan spiritual, disusul untuk status sosial dan aktualisasi diri; peningkatan taraf hidup dan bermanfaat untuk masa darurat. Melalui kelompok, warga mendapatkan berbagai informasi yang disampaikan pemerintah melalui penyuluh ataupun berbagai bantuan yang disalurkan oleh pemerintah.

Peningkatan taraf hidup yang dimaksud dari sisi manfaat, tidak hanya dirasakan secara individu namun secara kelompok, contohnya 
pengalokasian dana untuk paceklik atau dana kebersihan kampung dan destinasi wisata. Alokasi dana untuk paceklik, tabungan nelayan, dana sosial dan dana untuk sedekah laut menunjukkan bahwa tipe manfaat dari retribusi tersebut secara aktual dapat dinikmati kelompok sasaran nelayan dan menjamin kesejahteraannya. Tentang besarnya dana paceklik dan dana tabungan yang dimiliki oleh nelayan tergantung pada prosentase produktifitas dari anggota kelompok nelayan itu sendiri. Alokasi dana retribusi yang berupa dana sosial adalah alokasi dana yang disimpan dari hasil retribusi yang dipergunakan sewaktu-waktu untuk diberikan kepada nelayan yang mengalami kecelakaan di laut.

Karakter voluntaris dari kelompokkelompok yang diikuti warga juga tampak dari sumber dana utama bagi kegiatan kelompok. Berdasarkan tabel 2, nampak bahwa seluruh kelompok di pesisir bertumpu pada iuran anggota. Rata-rata iuran sebesar Rp.1.000,hingga Rp.5.000,- dikelola oleh bendahara dan dipertanggungjawabkan di hadapan anggota pada saat pertemuan-pertemuan.

Di Pantai Kwaru, pengelolaan dana kebersihan telah menggunakan kartu anggota dan ditarik setiap minggu dari warung atau rumah makan di pinggir pantai. Tiap rumah makan dikenakan retribusi kebersihan Rp.5.000,sedangkan bagi pengolah ikan dan warung kecil membayar Rp.3000,-. Administrasi yang baik ini patut dicontoh oleh kelompok sadar wisata di daerah lain. Fenomena yang lain dari Pokdarwis Goa Cemara, selain mengandalkan iuran anggota, kelompok ini mampu mengelola Rp.124.000.000,- lebih dari dana bantuan pemerintah, dana yang dipungut dari obyek wisata, retribusi kebersihan, parkir dan CSR.
Berdasarkan tabel 2, hanya kelompok keagamaan, pokwasmas, arisan, olah raga, profesi dan parpol, tidak mendapat dana bersumber dari obyek wisata. Amatan peneliti juga menunjukkan kelompok arisan ibu-ibu maupun bapak-bapak dan pengajian paling banyak mengadakan aktifitas pertemuan rutin. Meskipun dari sisi sumber dana, pengembangan kemampuan dan kegiatan kelompok, sebagian besar masih sangat mengandalkan masukan dari sesama anggota kelompok. Kegiatan keagamaan warga yang membutuhkan berbagai fasilitas seperti masjid maupun mushola di daerah pesisir, cukup terbuka bagi kegiatan CSR. Seperti pembangunan Masjid Catur Sakti yang diprakarsai Yayasan Beladiri Catur Sakti di pantai Samas. Dalam pengembangannya, jamaah setempat mampu menjaring dana untuk peringatan Idul Adha dan hari besar lainnya dan menyediakan fasilitas pengembangan PAUD serta pendidikan Baca Tulis Al Qur'an. Bahkan masjid ini cukup bermanfaat sebagai sarana pengembangan dakwah bagi para PSK yang bermukim di sana. Tidak sedikit dari mereka yang akhirnya kembali ke jalan yang benar, berwirausaha dan meninggalkan profesi lama sebagai PSK.

Rata-rata perbulan anggota kelompok mengeluarkan dana Rp.50.000-Rp.100.000,dialokasikan untuk dana sosial, iuran arisan dan lain-lain. Mereka pada umumnya tidak berkeberatan karena manfaat yang mereka dapatkan sebagai imbal baliknya. Namun ada juga karena keterbatasan ekonomi, beberapa informan menyatakan hanya ikut kelompok yang berkaitan dengan mata pencaharian secara rutin. Ia khawatir kalau terlalu banyak mengikuti arisan atau kelompok, saat tidak ada penghasilan, ia tidak dapat menyetorkan iuran (wawancara dengan ibu Saijah, pantai Samas, Juli 2014).

Tabel 2. Sumber Dana Kelompok Masyarakat Pesisir Bantul

\begin{tabular}{clcccc}
\hline No & \multicolumn{1}{c}{ Jenis Kelompok } & Iuran anggota & Sumber pemerintah & CSR & Obyek Wisata \\
\hline 1. & Tani/nelayan & $\mathrm{V}$ & $\mathrm{V}$ & $\mathrm{V}$ & \\
2. & Keagamaan & $\mathrm{V}$ & $\mathrm{V}$ & $\mathrm{V}$ & \\
3. & Olahraga & $\mathrm{V}$ & $\mathrm{V}$ & $\mathrm{V}$ & $\mathrm{V}$ \\
4. & Budaya & $\mathrm{V}$ & $\mathrm{V}$ & $\mathrm{V}$ & $\mathrm{V}$ \\
5. & Wanita nelayan & $\mathrm{V}$ & $\mathrm{V}$ & $\mathrm{V}$ & $\mathrm{V}$ \\
6. & Profesi & $\mathrm{V}$ & $\mathrm{V}$ & $\mathrm{V}$ & $\mathrm{V}$ \\
7. & Parpol & $\mathrm{V}$ & $\mathrm{V}$ & & \\
8. & Sadar Wisata & $\mathrm{V}$ & $\mathrm{V}$ & $\mathrm{V}$ \\
9. & Pokwasmas & $\mathrm{V}$ & $\mathrm{V}$ & &
\end{tabular}


Kelompok-kelompok yang diikuti warga pesisir umumnya menunjukkan karakteristik yang sama dalam sejumlah faktor, terutama menyangkut kesamaan lokasi dan kesamaan agama di antara anggota-anggotanya. Hal ini menegaskan dominasi peran kelompokkelompok keagamaan dan kewargaan di sekitar permukiman sebagai kelompok yang banyak diikuti warga. Namun, kemampuan kelompok untuk menjalin jejaring kerjasama dengan kelompok lainnya relatif cukup baik. Kontak nelayan di lokasi penelitian dengan nelayan ngandong berasal dari Pacitan, Pangandaran dan Cilacap atau pantai Utara misalnya, mencerminkan sikap terbuka nelayan setempat untuk bekerja sama dengan kelompok lain di luar komunitasnya.

Bahkan menurut para pengelola Shrimp, tenaga-tenaga tambak yang cukup terampil sengaja didatangkan dari kawasan Pantai Pangandaran untuk menggarap lahan tambak milik pengusaha-pengusaha tambak di Bantul. Dengan demikian dapat disimpulkan tidak ada kesulitan bagi komunitas nelayan menjalin kerja sama dengan kelompok lain dalam lingkungan komunitas yang sama untuk mencapai tujuan bersama.

Berbeda halnya dengan kelompok wanita nelayan. Melalui berbagai program pemberdayaan, pemerintah dalam hal ini DKP Bantul telah memfasilitasi kelompok wanita nelayan Niswati Bahari. Sejak berdirinya, kelompok ini dicita-citakan dapat memfasilitasi kebutuhan wanita nelayan. Melalui kelompok ini, diharapkan koordinasi kegiatan pemberdayaan wanita nelayan oleh pemerintah menjadi lebih mudah. Akan tetapi dalam perkembangannya, kelompok ini jejaring kerjanya masih terbatas dalam lingkup komunitas tersebut.

\section{Kepercayaan dan Solidaritas}

Kepercayaan dalam cakupan sub pembahasan ini meliputi kepercayaan kepada sesama; kepercayaan pada norma; kepercayaan kepada ketua kelompok; kepercayaan pada pemuka masyarakat dan kepercayaan pada pemerintah. Hubungan saling percaya dapat tumbuh apabila orang berlaku jujur dengan kejujuran akan tumbuh sikap fair dan paham egaliter, seseorang akan toleran karena itu ia akan mudah bermurah hati.

Hubungan saling percaya akan tumbuh dalam jaringan sosial yang menyediakan ruang bagi warganya untuk berpartisipasi setara, bermodal itulah akan bekerja prinsip-prinsip reprositas dan akan mendorong tumbuhnya solidaritas antar warga, selanjutnya terjadi kerjasama yang dengan adanya pranata dan saling percaya akan melahirkan keadilan. Hubunganhubungan individu dalam jaringan sosial akan berlangsung baik apabila mereka memiliki nilainilai dan sangsi-sangsi serta aturan-aturan yang disepakati sebagai acuan tindak, yang apabila dilaksanakan dengan tegas akan melahirkan hubungan saling percaya.

Dari sisi tingkat kepercayaan, para informan sebagian besar menilai mayoritas orang-orang di sekitarnya dapat dipercaya. Bahkan mereka tidak segan-segan menitipkan warung ikan, dagangan atau kebunnya kepada tetangga, maupun menitipkan anggota keluarga bila mereka terpaksa bepergian. Mereka lebih suka tetangganya bekerja di warung ikan daripada harus mempekerjakan orang di luar daerah. Fenomena di pantai Parangtritis agak berbeda, para pengusaha warung berdasar hasil wawancara, tidak mempersoalkan pegawainya dari luar komunitas atau dari dalam komunitas mereka:

"kalau di Parangtritis, pemilik warung punya pekerjaan lain, petani dan beternak, jadi warung harus ada yang tunggu. Kalau tidak ada anggota keluarga, kita gaji orang" (Wawancara dengan ibu Ati, Juli 2014)

Ini menunjukkan bahwa deposit kepercayaan di kalangan masyarakat sebenarnya masih cukup tinggi.

Dalam pergaulan sehari-hari, tingkat kepercayaan ini masih menunjukkan tingkat yang positif, kecuali dalam hal yang menyangkut keuangan. Temuan di lokasi riset cukup menarik, bahwa sebagian besar informan cenderung tidak percaya pada orang-orang lain atau orangorang tertentu dalam hal pinjam-meminjam uang. Tingkat kepercayaan yang membuahkan sikap solidaritas di kawasan pesisir ditunjukkan dengan mudahnya warga mendapat uluran tangan tetangga dan kerabat bila sedang kesusahan. Pemberi bantuan tidak selalu sosok juragan akan tetapi mereka yang memiliki karakter ekonomi yang setara. Akan halnya hubungan paternalistik juragan yang tidak setara dengan nelayan masih mendominasi. Tukar menukar barang masih ditemukan di antara warga pesisir Bantul, terutama di kawasan pantai Baru, pantai Kwaru dan pantai Goa Cemara. Sedangkan di pantai 
Samas dan pantai Parangtritis, barter barang sudah jarang sekali dilakukan.

Tingkat kepercayaan warga relatif tinggi meskipun terhadap orang-orang yang memiliki perbedaan latar belakang sosial, ekonomi dan budaya. Temuan menarik bahwa sebagian besar warga cenderung lebih percaya pada figur-figur yang menjalankan pranata atau norma sosial dan keagamaan, seperti guru, perawat dan dokter serta tokoh agama. Sementara tingginya tingkat kepercayaan pada orang-orang dari etnis yang sama merupakan kecenderungan yang normal karena kepercayaan juga dibentuk oleh dasar ikatan genealogis dan identitas yang sama.

Sekalipun rasa saling percaya antar warga masih tebal, kegiatan bergotong royong membersihkan lokasi wisata atau kampung tempat tinggal sering dilakukan. Warga merelakan tenaga, tempat, menyumbang makanan dan minuman ala kadarnya. Meskipun ada beberapa informan yang menyatakan makna gotong royong pun tampaknya telah mulai menunjukkan pergeseran karena tidak selalu harus berupa tenaga, tapi juga dalam bentuk lain seperti uang, saran dan fasilitas. Warga pesisir tidak berkeberatan untuk berpartisipasi dalam kegiatan-kegiatan bersama. Dengan kata lain, tingkat solidaritas warga sebenarnya masih cukup tinggi, hanya perwujudannya mulai mengalami perubahan. Mengingat banyak yang sibuk bekerja, mereka umumnya lebih suka menyumbangkan uang atau fasilitas untuk mendukung kegiatan-kegiatan bersama.

\section{Aksi Kolektif dan Kerjasama}

Kemanfaatan berkelompok sebagaimana telah diungkapkan pada sub sebelumnya, menunjukkan bahwa warga menilai aksi kolektif sebagai payung sosial dan ekonomi mereka. Umumnya, kegiatan kolektif yang dilakukan terkait dengan pelaksanaan kegiatan agama (tahlilan), pernikahan, penguburan, pengajian, dll., bersih desa/lingkungan, membangun sarana umum, siskamling, posyandu, dll. yang bersifat sosial.

Bila ada warga yang tidak berpartisipasi, tidak ada kritik atau sanksi terhadap yang bersangkutan. Terkadang ada himbauan terhadap warga yang tidak ikut dalam kegiatan komunitas. Himbauan ini biasanya diberikan oleh aparat pemerintah setempat, seperti RT/ RW atau Kepala Desa/Lurah sehingga aksi kolektif dan kerjasama sangat ditentukan oleh kesadaran pribadi warga. Meskipun sifatnya bukan pengucilan tetapi ketika ada bantuanbantuan dari pihak luar, warga yang tidak aktif akan mendapat kesempatan terakhir (wawancara dengan pemuka masyarakat J., Agustus 2014). Dengan demikian, dalam hal aksi kolektif dan kerjasama, kesadaran warga masih tergolong tinggi. Artinya, nilai kebersamaan ini dapat menjadi potensi yang dapat dioptimalkan.

Temuan lain, ketersediaan kelompok dan jejaring kerja dalam lingkungan masyarakat ada juga yang kurang memadai karena kerjanya tidak efektif untuk meningkatkan kesejahteraan warga miskin. Banyak anggota masyarakat yang tidak mengetahui keberadaan kelompok kelompok tersebut, seperti kelompok Niswati Bahari. Oleh karena itu sebagian besar wanita nelayan tidak menjadi anggota dalam kelompok-kelompok tersebut.

Faktor utama yang menyebabkan warga mau diajak berpartisipasi dalam kegiatan bersama lebih disebabkan kesadaran mereka bahwa kegiatan-kegiatan tersebut merupakan kepentingan mereka bersama, kewajiban bersama dan untuk menumbuhkan rasa kebersamaan di antara warga.

Cara yang paling efektif agar warga mau berpartisipasi dalam kegiatan bersama yakni dengan pengumuman dari pemimpin warga di antaranya oleh Ketua RT/Ketua RW atau bapak Dukuh kepada warganya. Disampaikannya bahwa kegiatan tersebut merupakan kepentingan bersama, kewajiban bersama dan untuk menumbuhkan rasa kebersamaan serta secara langsung diberi contoh oleh pemimpin warga dalam kegiatan tersebut.

Role model atau pemberian contoh ini merupakan cara tertinggi yang paling efektif untuk melibatkan warga dalam kegiatan bersama. Minimnya contoh dari pemimpin maka warga tidak akan mau terlibat dalam kegiatan bersama tersebut.:

"kami prihatin ada pengurus PUMP yang justru mengedarkan uang anggota kepada bukan anggota. Yang jadi sasaran kredit adalah para prostitusi di pantai ini, malah bukan kepada wanita nelayan. Kalau PSK pinjam kan besar, bisa dipatok bunga besar jadi oknum pengurus itu untung. Jelas tidak mau ke rakyat kecil"'( keluhan informan $\mathrm{G}$ dalam suatu in depht interview dengan peneliti, Juli, 2014. 
"Jadi pengurus itu bukan ketrampilan dan pendidikannya kok yang diutamakan. Nek di sini, yang penting bisa dikedepi, diidak sikile, manthuk, niku sik dingge (ungkapan yang artinya bisa diajak kerjasama)" (wawancara dengan informan $\mathrm{M}$, Juli 2014).

"gimana warga mau patuh, wong pimpinane men akon nek taksih ndekem (menyuruh tapi tidak berbuat/memberi contoh) (wawancara dengan informan M, Juli 2014).

\section{Pranata dan Nilai-Nilai Lembaga}

Pengembangan institusi-institusi dan aturan-aturan yang secara efektif membatasi tingkat eksploitasi terhadap sumber daya alam terus terjadi di masyarakat, tidak terkecuali di masyarakat pesisir yang menjadi lokasi riset ini. Persoalannya terletak pada cara atau mekanisme yang ada dalam suatu masyarakat untuk menumbuhkan tindakan kolektif atau collective action atau perilaku kerjasama kolektif atau cooperative collective behavior. Dalam sub bahasan tentang pranata ini akan difokuskan pada kesediaan warga membantu; kesediaan membayar dana kelompok dan tingkat kehadiran pada pertemuan kelompok.

Warga desa yang dipercaya menjadi pengurus inti dan ketua, bendahara dalam suatu kelompok pada umumnya adalah orang yang dianggap bersih dan memiliki sejumlah kualifikasi dan karakater. Karakter tersebut meliputi: warga desa sendiri, dapat diterima masyarakat, terpercaya, pekerja keras, relatif altruis, bersih, tegas dan adil, berani, berwibawa, jujur, bijaksana, luas wawasannya dan pergaulan, taat beragama, aktif dalam kegiatan kemasyarakatan, bertanggung jawab serta kemampuan ekonominya relatif baik.

Pengalaman pengelolaan destinasi wisata di pesisir Bantul yang relatif cukup baik dan persisten ditandai oleh adanya menjaga kekompakan di antara pengurus, kuatnya komitmen untuk menjalankan tugas meskipun tanpa imbalan materi. Selain itu, adanya ketegasan ketua dalam menegakkan aturan main, sabar menghadapi kritik dari masyarakat, bersikap terbuka, transparan dan menggunakan dana kelompok sesuai tujuan kelompok.

Kemampuanmembangunkonsensussemua pengelola wisata yang persisten ditandai oleh kemampuan warganya merumuskan konsensus bersama dalam menentukan cara pemanfaatan pasca panen dan sumber daya kelautan lainnya. Pada kasus-kasus persisten terlihat adanya fokus jelas yang akan dituju dan tujuan yang dituju itu melalui suatu pertimbangan matang yang dapat mengakomodasi kepentingan warga kolektif. Fenomena pantai Goa Cemara dapat menjadi contoh, pembukaan lokasi destinasi wisata Goa Cemara tahun 2009 diprakarsai pokdarwis sendiri dan difasilitasi pemkab Bantul. Dana patungan yang dihimpun melalui pinjaman/ talangan kas kelompok tani dipergunakan untuk membuka akses ke wilayah pantai. Anggota pertama pokdarwis ini selanjutnya mengangsur tiap bulan Rp.30.000,- ke kas kelompok. Meski mereka membangun kios ikan di Sultan Ground, diputuskan untuk tidak menjorok ke laut dan bukan bangunan permanen. Pengadaan warung ikan atau gubug-gubug ikan diutamakan bagi warga setempat meskipun warga di luar komunitas boleh andil melalui warga (ikatan kerja sama). Pengaturan lahan parkir hingga pembangunan pendopo wisata merupakan kerja keras yang patut diapresiasi. Kelompok inipun tak hentinya mengupayakan pemerataan akses bagi anggotanya agar dapat menikmati manfaat dari keikutsertaannya dalam kelompok.

Pada kasus-kasus persisten kekompakan itu terbina melalui pelibatan komponen dalam seluruh tahapan pengelolaan lokasi wisata sehingga tumbuh rasa kepemilikan yang tinggi. Pelibatan semua pihak dalam menetapkan suatu tindakan kolektif adalah bagian penting dari civic participation sesuai konsep Putnam (1993,1995) dan Uphof (1998) sehingga terjadi pengalihan kepentingan 'saya' menjadi' kita', yang pada gilirannya melahirkan kekompakan solidaritas dan rasa memiliki yang tinggi terhadap pengelolaan sumber daya. Kepecayaan antar warga dengan pengurus merupakan perekat kuat untuk terjalinnya kerjasama di antara stake holder pariwisata setempat.

Berikut adalah list aturan tidak tertulis yang dipegang oleh warga pesisir pantai di 4 lokasi riset yakni pantai Parangtritis, Pantai Baru, Pantai Kwaru dan pantai Goa Cemara: 
Tabel 3. Aturan tidak Tertulis di desa pesisir kabupaten Bantul

\begin{tabular}{|c|c|c|c|c|c|c|c|c|c|c|c|}
\hline \multirow[b]{2}{*}{ No } & \multirow[b]{2}{*}{$\begin{array}{c}\text { Jenis Aturan tidak } \\
\text { tertulis }\end{array}$} & \multicolumn{2}{|c|}{ P. Parangtritis } & \multicolumn{2}{|c|}{ P. Samas } & \multicolumn{2}{|c|}{ P. Baru } & \multicolumn{2}{|c|}{ P. Kwaru } & \multicolumn{2}{|c|}{ P. Goa Cemara } \\
\hline & & Ditaati & $\begin{array}{l}\text { Tidak } \\
\text { ditaati }\end{array}$ & Ditaati & $\begin{array}{l}\text { Tidak } \\
\text { ditaati }\end{array}$ & Ditaati & $\begin{array}{l}\text { Tidak } \\
\text { ditaati }\end{array}$ & Ditaati & $\begin{array}{l}\text { Tidak } \\
\text { ditaati }\end{array}$ & Ditaati & $\begin{array}{l}\text { Tidak } \\
\text { ditaati }\end{array}$ \\
\hline 1. & Tidak ada PSK & & $\mathrm{X}$ & & $\mathrm{X}$ & $\mathrm{X}$ & & $\mathrm{X}$ & & $\mathrm{X}$ & \\
\hline 2. & $\begin{array}{l}\text { Tidak ada } \\
\text { pengamen }\end{array}$ & & $\mathrm{X}$ & & $\mathrm{X}$ & $\mathrm{X}$ & & $\mathrm{X}$ & & $\mathrm{X}$ & \\
\hline 3. & $\begin{array}{l}\text { Tidak ada } \\
\text { pengasong }\end{array}$ & & $\mathrm{X}$ & & $\mathrm{X}$ & $\mathrm{X}$ & & $\mathrm{X}$ & & $\mathrm{x}$ & \\
\hline 4. & $\begin{array}{l}\text { Tidak menebang } \\
\text { pohon } \\
\text { sembarangan }\end{array}$ & $\mathrm{X}$ & & $\mathrm{X}$ & & $\mathrm{X}$ & & $\mathrm{X}$ & & $\mathrm{x}$ & \\
\hline 5. & Jujur & $\mathrm{X}$ & & $\mathrm{X}$ & & $\mathrm{X}$ & & $\mathrm{X}$ & & $\mathrm{X}$ & \\
\hline 6. & Ramah, helpfull & $\mathrm{X}$ & & $\mathrm{X}$ & & $\mathrm{X}$ & & $\mathrm{X}$ & & $\mathrm{X}$ & \\
\hline 7. & $\begin{array}{l}\text { Tidak mencuri } \\
\text { hewan, pasir } \\
\text { pantai yang } \\
\text { dilindungi }\end{array}$ & $\mathrm{X}$ & & $\mathrm{X}$ & & $\mathrm{X}$ & & $\mathrm{X}$ & & $\mathrm{X}$ & \\
\hline
\end{tabular}

Berdasarkan tabel di atas, nampak bahwa persoalan pengamen, pengemis dan pengasong masing-masing komunitas warga memiliki sikap yang berbeda. Pantai Samas dan Pantai Parangtritis lebih permisif terhadap keberadaan mereka sedangkan pantai Baru, pantai Goa Cemara menolak keberadaan mereka, dengan pertimbangan mereka ingin mengupayakan kawasan bebas Mo Limo/ kawasan bersih dan beriman. Pantai Parangtritis dan pantai Samas bahkan mengangap keberadaan prostitusi di wilayahnya sebagai aset untuk mendatangkan pengunjung ke pantai tersebut. Warga yang tidak berusaha di bidang pariwisata secara umum sebenarnya resah dan keberatan dengan keberadaan mereka yang dapat mempengaruhi perkembangan anak didik di daerah tersebut.

Konflik sosial yang terpendam ini apabila tidak segera dikaji oleh pembuat kebijakan setempat akan berdampak pada defisiensi modal sosial. Tanda-tanda defisiensi modal sosial itu ialah makin runtuhnya sendi-sendi kehidupan sosial yang harmonis, sulitnya membangun kerjasama, menguatnya rasa saling curiga antar berbagai komponen masyarakat, hilangnya hubungan saling percaya antarwarga dan warga masyarakat dengan pemerintah dan sebagainya.

Pada kasus persisten, seperti di pantai Goa Cemara dan pantai Baru serta Kwaru, adanya aturan-aturan diperkuat dengan adanya sistem norma dan nilai-nilai yang dianut bersama warga komunitas yang menjadi panduan moral bagi mereka dalam bertindak. Dalam pengelolaan sumber daya laut ada aturan dan sangsi-sangsi dibuat sendiri sesuai dengan kebutuhan dan kesanggupan mereka melalui konsesnsus dalam komunitas dilandasi kepercayaan bahwa aturanaturan itu dibuat untuk kepentingan kolektif. Oleh karena itu, kepatuhan warga terhadap aturan-aturan lebih bersikap sukarela atau trust best behaviour bukan coercion. Pengawasan terhadap penegakan aturan juga menjadi hak normatif semua warga komunitas dan mereka mendapatkan insentif atas partisipasinya dalam proses tersebut. Untuk kasus-kasus kriminalitas seperti pengeboman ikan, pencurian ada kalanya masyarakat cenderung untuk menyelesaikan di luar meja hijau.

Temuan menarik di lapangan bahwa suasana kemadanian ini tidak berlangsung secara simultan dan merata pada semua bidang kehidupan. Bahkan komunitas pesisir di kabupaten Bantul sendiri gagal mengembangkan modal sosial dalam konteks pengelolaan sumber daya yang berasal dari pemerintah seperti dana bangdes, JPS dsb (hasil wawancara dengan sejumlah pemuka masyarakat di pantai Baru, Samas, Kwaru dan Parangtritis). Elemen pokok modal sosial menjadi runtuh oleh kepentingan sesaat karena kucuran dana yang terkadang menggelapkan mata dan nurani pengurusnya. Padahal hakekatnya, elemen modal sosial dapat didayagunakan oleh warga komunitas melalui mekanisme sosial yang kondusif dengan memanfaatkan medium-medium pertukaran informasi yang sudah ditradisikan, adanya sikap toleran kepada keragaman, format pengeloaan yang disesuaikan dengan 
konteks keadaan, kebutuhan, kemampuan dan kondisi sosial budaya sosial dan mekanisme pertanggungjawaban publik atas seluruh proses pengelolaan.

\section{Akses, Manfaat dan Kontrol Perempuan terhadap Pengelolaan Potensi Pesisir}

Berdasarkan data empiris di lapangan, aktivitas perikanan dan kelautan yang dilakukan oleh laki-laki dan perempuan di desa pesisir kabupaten Bantul dengan segala akses dan kontrol yang menyertainya, menyebabkan timbulnya relasi gender yang tidak seimbang.

Ketidakseimbangan relasi gender ini dapat dilihat dari beberapa aspek. Pertama, pada pola penguasaan sumber daya. Meski ada pelibatan saat ada perjanjian hutang atau kredit dari bank dan bantuan pemerintah, jumlah dana bantuan untuk wanita nelayan masih minim. Persoalan ini cukup signifikan meski perempuan (istri) terkadang kurang menyadarinya. Para istri ini kerap menganggap bahwa pelekatan nama mereka dalam akta perjanjian bukanlah masalah yang harus dipersoalkan sebab yang paling penting adalah akses mereka pada pinjaman tersebut. Jika para suami mereka sudah memilikinya maka mereka juga sudah dapat mengelolanya untuk peningkatan kesejahteraan rumah tangga mereka. Para istri ini tidak pernah membayangkan bahwa pelekatan nama mereka pada akta perjanjian atau sertifikat memiliki arti penting yang lebih dalam yakni apabila terjadi sesuatu dalam kehidupan mereka seperti perceraian atau kematian suami.

Tabel 4. Aksesibilitas, Kontrol dan Manfaat terhadap Sumber Daya Pesisir

\begin{tabular}{llcc}
\hline No. & \multicolumn{1}{c}{ Akses } & Laki-laki & Perempuan \\
\hline 1. & Dana & $\sqrt{ }$ & $\sqrt{ }$ \\
2. & Informasi & $\sqrt{ } \sqrt{ }$ & $\sqrt{ }$ \\
3. & Pelatihan & $\sqrt{ } \sqrt{ }$ & $\sqrt{ }$ \\
\hline$\sqrt{ } \sqrt{ }=$ dominan & & \\
$\sqrt{ }=$ relatif kecil & &
\end{tabular}

Aksesibilitas masyarakat pesisir pada sumber informasi, berdasarkan survey dan wawancara mendalam di lokasi penelitian, akses (peluang dan kesempatan) yang dimiliki lakilaki lebih dominan daripada perempuan dewasa (istri). Untuk sumber informasi seperti televisi, laki-laki dan perempuan memiliki kesempatan yang sama. Penggunaan media informasi televisi ini, tampaknya cukup dominan dalam keluarga karena lebih menarik secara visual dan alternatif acara beragam. Jaringan internet sudah masuk di desa pesisir Bantul dan masih sedikit orang yang dapat menggunakannya, sedangkan media radio jarang digunakan oleh masyarakat karena peran dan fungsinya telah tergantikan oleh televisi. Tidak hanya laki-laki dewasa dan perempuan dewasa yang bisa mengakses media ini, tetapi juga anak-anak baik laki-laki maupun perempuan memiliki akses yang sama. Hal ini karena mereka memiliki acara atau program yang berbeda dalam waktu yang berbeda sehingga mereka mengakses televisi dengan cara bergiliran.

Kedua, pada sistem pengolahan pasca panen dan distribusi hasil laut dan perikanan. Pembagian kerja dalam masyarakat pesisir pada umumnya, laki-laki bertanggung jawab untuk melaut dan wanita nelayan mendistribusikannya atau berperan sebagai pemasar ikan. Bahkan anak-anak kerap difungsikan untuk membantu orang tua mereka. Ini dilakukan agar pengelolaan sumber daya kelautan memberikan hasil yang maksimal (tabel 5). Tidak sedikit waktu bermain dan belajar anak-anak pesisir berkurang karena harus membantu orang tuanya.

Peran dan partisipasi perempuan dalam aktivitas perikanan kelautan ini, ternyata tidak berbanding seimbang dengan kewenangan yang mereka miliki. Dalam beberapa hal perempuan dilibatkan pada pengambilan keputusan, tetapi dalam hal yang lain, perempuan justru tidak dilibatkan dalam pengambilan keputusan, meskipun keputusan tersebut memiliki kaitan yang cukup signifikan bagi urusan kesejahteraan rumah tangga. Pelibatan perempuan dalam pengambilan keputusan biasanya hanya seputar pemasaran di pasar ikan. Keputusan akhir dalam penentuan pinjaman, pemasaran melalui TPI biasanya tetap dimiliki oleh suami (tabel 6). 
Tabel 5. Pembagian Kerja Panen hingga Pasca Panen

\begin{tabular}{llccc}
\hline No. & \multicolumn{1}{c}{ Kegiatan } & Suami & Istri & Anak \\
\hline 1. & Melaut & $\sqrt{ } \sqrt{ }$ & - & - \\
2. & $\begin{array}{l}\text { Memilah Ikan } \\
\text { hasil Tangkapan }\end{array}$ & - & $\sqrt{ }$ & - \\
& $\begin{array}{l}\text { Pengolahan } \\
\text { 3. }\end{array}$ & $\sqrt{ }$ & $\sqrt{ } \sqrt{ }$ & $\sqrt{ }$ \\
& $\begin{array}{l}\text { Pasca Panen } \\
\text { Pemasaran ke }\end{array}$ & $\sqrt{ }$ & - & - \\
& $\begin{array}{l}\text { TPI } \\
\text { Pemasaran } \\
\text { ke Pasar dan } \\
\text { tempat Wisata }\end{array}$ & $\sqrt{ }$ & $\sqrt{ } \sqrt{ }$ & $\sqrt{ }$ \\
\hline
\end{tabular}

$\sqrt{ } \sqrt{ }=$ dominan

$\sqrt{ }=$ relatif kecil

Sistem ini memarginalkan peran perempuan. Istri hanya dilibatkan dalam komunikasi awal untuk menentukan bentuk penjualan. Selain keputusan akhir ada di tangan suami, distribusi hasil panen ikan ini juga tidak memberikan ruang kepada istri untuk bernegosiasi dengan calon pembeli terkait dengan harga yang mereka inginkan. Padahal, hasil penjualan tersebut akan dimanfaatkan untuk keperluan rumah tangga dimana istri yang mengetahui betul kondisi keuangan rumah tangga mereka. Jika demikian maka posisi istri tidak cukup signifikan dalam menentukan besarnya pendapatan guna pemenuhan kebutuhan rumah tangga mereka.

Ketiga, pada aktivitas level rumah tangga. Aktivitas level rumah tangga biasanya sering dimaknai sebagai aktivitas domestik. Dalam masyarakat pesisir, aktivitas domestik ini banyak diemban oleh perempuan (istri). Curahan waktu yang dimiliki istri untuk mengurus aktivitas rumah tangga lebih banyak dibandingkan dengan laki-laki. Selain karena konstruksi budaya yang masih menempatkan istri pada wilayah domestik, aktivitas rumah tangga yang demikian juga disebabkan oleh adanya anggapan bahwa tugas utama nelayan adalah melaut atau bertani di lahan atau kebun sehingga mereka hanya sekedar membantu istri apabila dibutuhkan. Curahan waktu yang harus dikeluarkan oleh istri lebih banyak dibanding dengan curahan waktu yang dikeluarkan oleh suami. Aktivitas domestik yang selalu dibebankan kepada istri tidak mengurangi peran dan beban kerja mereka di lahan garapan. Hal ini menunjukkan bahwa beban ganda (double burden) masih dialami oleh wanita nelayan. Peran ganda perempuan ini dipengaruhi oleh norma-norma yang dianut dan dipraktekkan pada akhirnya menempatkan perempuan dalam posisi yang lebih rendah dibanding dengan laki-laki. Norma-norma tersebut pada dasarnya adalah pola diskriminasi terhadap perempuan dalam berbagai bentuk karena perbedaan jenis kelamin laki-laki dan perempuan. Selain internalisasi norma-norma ketidakadilan gender tersebut juga dipengaruhi oleh akses dan kontrol perempuan terhadap fasilitas dan layanan publik.

Tabel 6. Pengambilan Keputusan dalam Rumah Tangga Nelayan

\begin{tabular}{llcc}
\hline No. & Kegiatan & Suami & Istri \\
\hline 1. & Keperluan Rumah & $\sqrt{ }$ & $\sqrt{ } \sqrt{ }$ \\
& $\begin{array}{l}\text { Tangga } \\
\text { 2. }\end{array} \quad \begin{array}{l}\text { Pinjaman Usaha/ } \\
\text { Modal }\end{array}$ & $\sqrt{ } \sqrt{ }$ & $\sqrt{ }$ \\
3. & Pemasaran & $\sqrt{ } \sqrt{ }$ & $\sqrt{ }$ \\
$\sqrt{ } \sqrt{ }=$ dominan & & \\
$\sqrt{ }=$ relatif kecil & &
\end{tabular}

\section{Dampak Pemberdayaan Masyarakat Pesisir bagi Wanita Nelayan}

Berdasarkan studi dokumentasi

riset sebelumnya (Anggraini, 2008; 2013) menunjukkan penguatan ekonomi lokal di pesisir kabupaten Bantul melalui lembaga modern seperti Swa Mitra Mina dan bank-bank swasta, cukup resisten dan seolah menjadi ancaman bagi organisasi ekonomi lokal. Proses pemberdayaan ekonomi melalui PNPM Mandiri Pariwisata \& PNPM MKP (Laporan PNPM DIY, 2010; Sahudiyono, 2009) belum diikuti penguatan lembaga lokal, yang memberi ruang partisipasi yang lebih luas bagi wanita nelayan sehingga proses peningkatan kapasitas pun belum banyak dinikmati anggota. Bantuan justru menyebabkan modal sosial masyarakat berupa kejujuran dan kegotong-royongan terkikis. Kelompok nelayan dan kelompok wanita nelayan binaan Diskanla Kabupaten Bantul belum seluruhnya mampu memanfaatkan modal sosial untuk meningkatkan usahanya, yang tercermin dari keterbatasan akses, partisipasi, kontrol dan manfaat yang diterima.

Dari berbagai penelitian dan pengamatan, permasalahan yang seringkali dialami wanita 
nelayan:

- Terbatasnya akses permodalan.

- Terbatasnya akses pasar, produksi pasca panen seringkali tidak dapat terserap pasar karena kurangnya akses informasi dan teknologi yang tepat guna.

Dari sisi penyelenggara program:

- Kentalnya presepsi stereotipe gender di kalangan penentu dan pelaksana program serta masyarakat yang sangat kental pada stereotipe peran domestik menjadikan kegiatan-kegiatan pengentasan kemiskinan cenderung dominan dalam memenuhi kebutuhan praktis dan kurang dalam pemenuhan kebutuhan strategis gender. Program yang cenderung tidak berkelanjutan berakibat pada kurangnya peningkatan ketahanan pangan.

- Lemahnya sosialisasi dan penunjukan lembaga pelaksana yang kurang tepat, banyak program yang keberhasilannya sangat ditentukan oleh kapasitas dan kapabilitas lembaga pelaksana dan SDM yang mengelolanya.

- Belum terintegrasinya pendampingan usaha (UB) yang menggunakan pendekatan partisipatif berprespektif gender yang mencakup pendampingan dari sisi produksi maupun pemasaran sehingga sekalipun ada keberlanjutan usaha bersama namun kotribusinya sebatas pada strategi survival.

- Lemahnya pengawasan dari masyarakat, hal ini menyebabkan banyak upaya terhenti dan tersendat setelah ditinggalkan fasilitator/ pendamping; dengan adanya Otonomi Daerah, hal ini menyebabkan sulitnya instansi pusat dalam mengontrol dan memantau pelaksanaan upaya karena terputusnya link pemerintah pusat pada pemerintah kabupaten/kota.

Intervensi yang dapat dilakukan:

- Dilaksanakannya aksi afirmatif (affirmative action) guna meningkatkan akses dan kontrol wanita nelayan terhadap lahan usaha perikanan melalui penditribusian lahan tidur, lahan tambak dengan pemberian bantuan input, penguatan modal atau bergulir, ternak, alat penangkapan ikan dan budidaya ikan dan tanaman produktif lainnya disertai dengan pendampingan manajemen usaha yang berwawasan agriculture baik dari sisi kelembagaan dan dalam skala rumah tangga.

- Pengembangan kapasitas SDM juga dapat diarahkan untuk memberikan bekal dan menyiapkan kaum perempuan untuk memasuki dunia baru (melaksanakan kegiatan baru) yang lebih menjanjikan.

- Dilaksanakannya aksi afirmatif pemberdayaan keluarga nelayan serta pelaku usaha lainnya dalam penyelenggaraan program dan proyek perikanan dan kelautan dengan pendekatan partisipatif yang berprespektif gender sejak perencanaan, pelaksanaan, pemantauan dan evaluasinya.

- Dilaksanakannya penyadaran gender khususnya dalam hal sistem alokasi sumber daya aset produksi (lahan usaha tambak, alat atau pelengkapan penangkapan dan budidaya perikanan.

- Dikembangkannya usaha kecil/ mikro yang dikelola perempuan disertai dengan pelayanan atau konsultasi bisnis atau pendampingan usaha yang dapat menfasilitasi mereka terhadap akses sumber daya agar sisi supply dan demand sehingga mampu meningkatkan pendapatan mereka.

- Melaksanakan tindakan afirmasi untuk mendorong partisipasi perempuan sebagai anggota dan pengurus kelompok wanita nelayan dan kelompok usaha secara proporsional.

\section{SIMPULAN}

Karakeristik modal sosial masyarakat pesisir di lokasi penelitian menunjukkan bahwa kelompok dominan adalah kelompok warga (arisan, RT), pengajian, kelompok nelayan dan wanita nelayan. Mengingat kelompok yang dominan berada di lingkungan internal permukiman dan beranggotakan masyarakat permukiman itu sendiri, akses terhadap sumber daya dari luar terbatas. Tingkat partisipasi dalam kelompok cukup baik dilihat dari kehadiran, materi dan non materi. Tingkat kepercayaan dan solidaritas relatif tinggi. Nilai-nilai masih dipegang teguh dan membuahkan aksi kolektif dan kerjasama relatif cukup baik.

Modal sosial lebih banyak dimanfaatkan untuk pemenuhan kebutuhan sehari-hari (subsisten), bersifat temporer dan sangat personal. Masih ada budaya lokal yang kurang mendukung, hidup boros. Tidak banyak jenis pelayanan yang dapat diperluas aksesnya karena keberadaan kelompok yang terbatas. Kecenderungan untuk berhubungan dengan orang-orang dengan latar belakang yang setara sehingga akses terhadap permodalan, informasi, teknologi dan pasar terbatas, terutama pada wanita nelayan. 
Modal sosialyang mendukung pengelolaan destinasi wisata dan pemberdayaan masyarakat pesisir pada umumnya perlu penguatan dari instansi terkait terutama DKP, Dinpar dan Disperindagkop pemkab Bantul secara lebih terpadu. Ketidakhati-hatian pemrakarsa pemberdayaan pesisir mengakibatkan komunitas pesisir di kabupaten Bantul sendiri gagal mengembangkan modal sosial dalam konteks pengelolaan sumber daya yang berasal dari pemerintah seperti dana bangdes, JPS dsb.

Program pemberdayaan masyarakat pesisir lebih berorientasi pada perikanan tangkap dan bias gender. Sementara keterlibatan wanita nelayan dalam proses produksi dan distribusi perikanan sangat besar, tetapi hal tersebut tidak disertai dengan kontrol atau pemberian kewenangan yang proporsional. Wanita nelayan seringkali absen dalam menentukan atau memberi keputusan akhir pada aktivitas pengelolaan perikanan dan kelautan yang mereka lakukan. Di samping itu pada level domestik dan publik, istri masih harus mengalami beban ganda (double burden). Hal inilah yang mengakibatkan relasi gender yang terdapat dalam kehidupan nelayan belum seimbang (equal).

Dalam skala rumah tangga, dilaksanakannya aksi afirmatif (affirmative action) guna meningkatkan akses dan kontrol wanita nelayan sebagai anggota kelompok wanita nelayan sehingga dapat mengelola usaha secara lebih efisien dan produktif melalui serangkaian pelatihan dan pendampingan.

Dilaksanakannya aksi afirmatif pemberdayaan keluarga nelayan serta pelaku usaha lainnya dalam penyelenggaraan program dan proyek perikanan dan kelautan dengan pendekatan partisipatif yang berprespektif gender sejak perencanaan, pelaksanaan, pemantauan dan evaluasinya.

Dari sisi kelembagaan, perlu dilaksanakannya tindakan afirmasi untuk mendorong partisipasi perempuan sebagai anggota dan pengurus kelompok wanita nelayan dan kelompok usaha secara proporsional, pendampingan bagi wanita nelayan dalam aspek manajerial, produksi dan pemasaran. Penguatan jaringan sosial antar kelompok organisasi dapat berfungsi sebagai paguyuban, sumber informasi dan transfer teknologi yang sesuai. Selain itu, dapat sebagai payung ekonomi melalui pengembangan kapasitas koperasi/arisan, kelompok-kelompok lokal masyarakat pesisir yang menunjang pengembangan potensi pesisir.

\section{DAFTAR PUSTAKA}

Anggraini, Oktiva. 2006. "Kajian Restrospektif Program Pemberdayaan Ekonomi Masyarakat Pesisir" dalam Jurnal Kebijakan dan Administrasi Publik UGM, volume 10, Mei 2006. http://jurnal.ugm. ac.id/ikap.

,Pemberdayaan Kelompok Wanita NelayanmelaluiPNPMMandiriPariwisata dalam Pengembangan Ekowisata Pantai Depok di Kabupaten Bantul http:// repository.widyamataram.ac.id/uploads/ pdfs/2011 - PROSIDING DOSEN KOPERTIS_WIL.V_YOGYA_2011_pdf

, "Marginalisasi Masyarakat Nelayan" dalam Jurnal Padma Sri Kresna UWMY, no.10 vol.2 November Th. 2006. http:// repository.widyamataram.ac.id/uploads/ pdfs/2006 - JURNAL PADMA VOL. 2 NO .10 NOPEMBER 2006.pdf

, Upaya Peningkatan Partisipasi Kelompok Wanita Nelayan dalam Pengembangan Wisata Kuliner dan Ekonomi Kreatif Pantai Baru, Poncosari Kabupaten Bantul. http://repository. widyamataram.ac.id/uploads/pdfs/2013 JURNAL_POPULIKA_VOL.IV_NO_.6 DESEMBER_2013_pdf

Bennet, E Vallete., HR Maiga. eds. 2004. Room to manoeuvre: gender and coping strategies in the Fisheries Sector, Porsmoth, U K, IIDRA.

Coleman, J. 1988. Social Capital in the Creation of Human Capital, American Journal of Sociology.

Eaton, Joseph W. 1986. "Petunjuk bagi Perumusan Teori Pembangunan" dalam Pembangunan Lembaga dan Pembangunan Nasional: dari Konsep ke Aplikasi. Editor J.W. Eaton. UI Press. Jakarta. Hal 157 - 167.

FAO, 2012, Selected Issues in Fisheries and Aquaculture, National Aquaculture Sector Overview, NASO Facts Sheet. 
Fukuyama, Francis. 1999. Social Capital and Civil Society. Institute of Public Policy. George Mason University.

2003. Social Capital and Economic Development. Routledge. London.

Hasbullah, Jousairi. 2006, Sosial Capital, Menuju Keunggulan Budaya Manusia Indonesia, Jakarta: MR-United Press.

Hendarti, Paulina Ratna, 1975. Perbedaan Orientasi Nilai Budaya Antara Generasi Muda dan Orang Tua Golongan Keturunan Cina. Jakarta: Leknas. Jurnal Penelitian dan Pengembangan Sains\& Humaniora 5 (3), 236-258 JPPSH, Lembaga Penelitian Undiksha, Desember 2011.

Hermawanti dan Hesti Rinandari. 2002. Penguatan dan Pengembangan Modal Sosial Masyarakat Ada, dalam Copyright (a) 2003 Institute For Research and Empowerment.

Laporan PNPM DIY, 2010;

Ostrom, E. 1990. Governing the Commons: the Evaluation of Institutions for Collective Action, Cambridge University Press, New York.

Sahudiyono. 2009. Pemberdayaan Ekonomi Mayarakat Pesisir (PEMP) di Wilayah Pesisir Kabupaten Bantul, Tesis, UGM.

Syahyuti. 2003. Bedah Konsep Kelembagaan: Strategi Pengembangan dan Penerapannya dalam Penelitian Pertanian, Pusat Penelitian dan Pengembangan Sosial Ekonomi Pertanian. Badan Litbang Pertanian. Bogor.

Sutoro, Eko. 2004. Modal Sosial, Desentralisasi dan Demokrasi Lokal, dalam Jurnal Analisis CSIS, Vol. 33,No.3, Sept, Jakarta: CSIS.

Wahyuni, Sri. 2007. "Modal Sosial sebagai Usaha Mengurangi Kemiskinan Masyarakat Nelayan pada Tinjauan Prespektif Gender" dalam Jurnal Aplikasi Administrasi vo. 9 no. 1 Mei. 